\title{
Full-sib reciprocal recurrent selection in the maize populations Cimmyt and Piranão
}

\author{
K.S. da Cunha ${ }^{1}$, M.G. Pereira ${ }^{1}$, L.S.A. Gonçalves ${ }^{1}$, A.P.C.G. Berilli ${ }^{2}$, \\ E.C. de Oliveira ${ }^{1}$ H.C.C. Ramos $^{1}$ and A.T. do Amaral Júnior ${ }^{1}$ \\ ${ }^{1}$ Universidade Estadual do Norte Fluminense Darcy Ribeiro, \\ Campos dos Goytacazes, RJ, Brasil \\ ${ }^{2}$ Instituto Federal do Espírito Santo, Campus Itapina, Colatina, ES, Brasil \\ Corresponding author: M.G. Pereira \\ E-mail: messias@uenf.br
}

Genet. Mol. Res. 11 (3): 3398-3408 (2012)

Received October 17, 2011

Accepted March 30, 2012

Published September 25, 2012

DOI http://dx.doi.org/10.4238/2012.September.25.8

\begin{abstract}
We estimated the genetic gains of the 12th cycle of reciprocal recurrent selection for maize traits of agronomic interest. We used 23 ISSR molecular markers in an attempt to maximize genetic variability among and within populations based on selection of $\mathrm{S}_{1}$ progenies. To this end, 138 full-sib families were evaluated in a randomized block design in two environments (the municipalities of Campos dos Goytacazes and Itaocara, in the State of Rio de Janeiro, Brazil), with replications within sets. Direct selection for grain yield was used for the selection of the families. To assess genetic diversity among and within populations, we examined plants produced from part of the $S_{1 \mathrm{~s}}$ seeds from the parents that originated the 42 full-sib families that were selected from the agronomic traits. Direct selection for grain yield provided good gains for the traits evaluated, with estimated improvement of -0.87 days for days to flowering, 0.35 plants, 1.79 ears per plot, $0.58 \mathrm{~g}$ per 100-grain weight, $308.21 \mathrm{~g}$ ear weight per plot, and $261.83 \mathrm{~kg} / \mathrm{ha}$ grain yield. Application of molecular markers at the stage of superior progeny selection led to increased genetic distance among populations, which is a very important factor for maximizing the
\end{abstract}


utilization of heterosis and providing greater longevity to the reciprocal recurrent selection program.

Key words: Zea mays L.; Direct selection; Genetic gains; Full-sib families

\section{INTRODUCTION}

Maize (Zea mays L.) plays an important role in global agribusiness. It is estimated that worldwide production was around 818 million tons in the 2009/2010 harvest. The United States, China and Brazil are the largest producers, responsible for 41, 20 and 7\% of the world's production, respectively (Food and Agriculture Organization of the United Nations, FAO, 2011).

Genetic breeding, with the exploitation of heterosis or hybrid vigor, is considered one of the main factors that have affected the progress of maize crops in the world (Springer and Stupar, 2007). However, most seeds of maize hybrids available for commercial breeding show a reduced genetic base, mainly due to strong commercial pressures that force breeders to extract a narrow range of the elite germplasm tested (Goodman, 2005; Mikel and Dudley, 2006; Hartings et al., 2008; Fan et al., 2010; Reif et al., 2010). Moreover, elite lines developed in breeding programs are recycled repeatedly to join their favorable alleles in new inbred lines and hybrids (Bernado, 2008; Souza Jr. et al., 2010).

Although these procedures may be considered effective for the development of hybrids, in the long term, this reduced genetic variability can lead to genetic vulnerability to biotic and abiotic stresses and limited future selection gains (Smith et al., 2004; Reif et al., 2010; Souza Jr. et al., 2010; Romay et al., 2011). Therefore, the exploration of new sources of germplasm and the adoption of other breeding strategies can be considered an alternative for long-term maize breeding progress.

Reciprocal recurrent selection (RRS), proposed by Comstock et al. (1949), is a method to improve the performance of the crossing of two populations of different heterotic groups. The main focus of the method is the simultaneous selection for general and specific ability, exploring various mechanisms of gene action (additivity, dominance, overdominance, and epistasis; Hallauer and Miranda Filho, 1988).

According to Hallauer et al. (2009), RRS is considered to be well suited for extracting lines aimed at the formation of hybrids, because populations become increasingly productive per se and in crosses between them. Meanwhile, the crosses of the lines extracted from improved populations become increasingly heterotic as the number of selection cycles increases. Furthermore, the strains developed in RRS programs are not related to the strains developed in recycling programs. Therefore, these lineages could be incorporated into these programs to maintain the rate of development and launch of new hybrids (Souza Jr. et al., 2010).

The Universidade Estadual do Norte Fluminense Darcy Ribeiro (UENF) has developed a program aimed at increasing RRS yield and other agronomic traits of economic interest of the populations Cimmyt (flint type) and Piranão (dent type). To increase the efficiency of the RRS, the program has adopted the use of marker-assisted selection aimed at monitoring the genetic variability of the populations that are being worked and selecting families to be recombined to maximize heterosis among populations (Tardin et al., 2007; Berilli et al., 2011).

This study aimed to estimate the genetic gains planned for the 12th cycle of reciprocal recurrent selection for traits of agronomic interest and to maximize, by means of inter-simple 
sequence repeat (ISSR) molecular markers, the variability of the populations Cimmyt and Piranão, based on the $S_{1}$ progeny selected by selection index.

\section{MATERIAL AND METHODS}

\section{Plant material}

Two populations belonging to different heterotic groups, Cimmyt (flint type) and Piranão (dent type), were evaluated. Both populations were subjected to 11 cycles of RRS. The five initial cycles were carried out by the Universidade Federal de Viçosa (UFV) and the remaining cycles, by the UENF.

\section{Achievement of $S_{1 s}$ and full-sib families}

In March 2008, the populations Cimmyt and Piranão were sown in the UENF experimental field (Campos dos Goytacazes, RJ, Brazil) to obtain interpopulation full-sib and $\mathrm{S}_{1}$ families. For this purpose, a sample of two populations from the previous recurrent selection cycle was sown in alternate 6.00 -m rows, spaced $1.00 \mathrm{~m}$ between rows and $0.40 \mathrm{~m}$ between furrows. Thirty days after emergence, thinning was performed, with one plant per hole.

To obtain the interpopulation full-sib and $\mathrm{S}_{1 \mathrm{~s}}$ families, the following procedures were adopted: the ears were covered with transparent plastic bags before stigmata release. Simultaneously, the tassels were covered to prevent contamination. The crosses were carried out in prolific plants selected within each pair of rows, so that the first ear (top) was the product of self-fertilization and the second ear was produced by inter-population crosses. Thus, we obtained 138 full-sib families and 276 self-fertilized progenies $\left(\mathrm{S}_{1}\right)$. The $\mathrm{S}_{1}$ seeds were stored in a cold chamber, and the interpopulation full-sib families were used for evaluation trials.

\section{Evaluation and selection of full-sib progenies}

The 138 interpopulation full-sib families were evaluated in the 2008/2009 agricultural year, in a randomized block design in two environments (Campos dos Goytacazes and Itaocara, in the State of Rio de Janeiro), with replications within sets. The experimental plots consisted of single $5.00-\mathrm{m}$ rows, with spacing of $1.00 \mathrm{~m}$ between lines and $0.20 \mathrm{~m}$ between plants. Three seeds were sown per hole at a depth of $0.05 \mathrm{~m}$. Thinning was performed 21 days after emergence and one plant was placed in each hole.

The following agronomic traits were evaluated:

- number of days for flowering (NDF) - number of days from planting until the emergence of style-stigma of the ear of $50 \%$ of the plants of the experimental unit;

- number of plants (NP) - total number of plants during harvest;

- number of ears (NE) - total number of harvested ears;

- weight of 100 grains (W100) - weight, in grams, of a sample of 100 healthy grains.

- weight of ears (WE) - weight, in grams per plot, of the husked ears, and

- grain yield (GY) - achieved by weighing the grains in each plot, after threshing, and expressed in $\mathrm{kg} / \mathrm{ha}$.

The data of the agronomic traits were used for the analysis of variance, according to 
the statistical model

$$
Y_{i j k l}=\mu+E_{i}+S_{j}+E_{i j}+R / E S_{i j k}+F / S_{j 1}+E F / S_{i j 1}+\xi_{i j k l},
$$

where $Y_{i j k l}$ is the average phenotypic value of the plot; $\mu$ is the average; $E_{i}$ is the fixed effect of the i-th environment; $S_{j}$ is the effect of the j-th set; $E S_{i j}$ is the effect of the interaction between environments and sets; $R / E S_{i j k}$ is the effect of the $\mathrm{k}$-th replication within the interaction between the i-th environment and the $\mathrm{j}$-th set; $F / S_{j l}$ is the random effect of the $\mathrm{i}$-th genotype within the j-th set; $E F / S_{i j l}$ is the effect of the interaction between environments and genotypes within the j-th "set", and $\xi_{i j k l}$ is the experimental error. The estimates of the components of variance were determined. The estimator of the genotypic variance among families was expressed by:

$$
\hat{\sigma}_{G}^{2}=\frac{M S F / S-M S R}{\Theta r},
$$

where $M S F / S=$ mean square of families within "sets"; $M S R=$ mean square of the residue; $r$ $=$ replication, and $e=$ environment. The phenotypic variance was expressed by the following equation:

$$
\hat{\sigma}_{p}^{2}=\frac{M S F / S}{\Theta r} .
$$

The variance of the genotype versus environment interaction was determined by the equation:

$$
\hat{\sigma}_{G E}^{2}=\frac{\frac{M S(E * F)}{S}-M S R}{r} \frac{\varepsilon-1}{\theta},
$$

where $M S(E x F) / S=$ mean square of the families versus environment interaction within sets. Heritability based on the average of families was estimated by the expression:

$$
\hat{h}_{X}^{2}=\frac{\hat{\sigma}_{C}^{2}}{\frac{\partial}{\partial} \tilde{P}}=\frac{\frac{M S F}{S}-M S R}{\frac{M S F}{S}} .
$$

The percent genetic variation coefficient $\left(\mathrm{CV}_{\mathrm{g}}\right)$ was determined by:

$$
C V_{g}=100 \sqrt{\frac{\sigma_{g}^{2}}{M S R}} \text {, and the index of variation, by: } I_{v}=\frac{C V_{g}}{C V_{g}} \text {. }
$$

The direct gains for grain yield were predicted by the following expression: $\Delta \mathrm{M}=\mathrm{p}$ $\mathrm{x}$ DS x h${ }^{2}$ (Lynch and Walsh, 1998), where $p$ is the parent control and $D S$, the selection differential. The indirect gains were calculated by the expression

$$
\Delta \mathrm{M}_{\mathrm{p}(\mathrm{GY})}=\mathrm{p} \times \mathrm{DS}_{\mathrm{p}(\mathrm{GY})} \times \mathrm{h}^{2} \text { (Lynch and Walsh, 1988), }
$$

where $D S_{p(G Y)}$ is the differential of indirect selection, determined by the difference between the averages of the characteristics of the individuals selected based on the average grain yield and general average. 


\section{Assessment of genetic diversity by the ISSR technique}

Plants from part of the $S_{1 \mathrm{~s}}$ seeds of the parents that originated the 42 full-sib families selected by the selection index were used to assess the genetic diversity within and between the populations Cimmyt and Piranão.

Total cell DNA was extracted according to Doyle and Doyle (1990), with modifications suggested by Daher et al. (2002). After DNA extraction, DNA was quantified on $1.0 \%$ agarose gels. The DNA High Mass Ladder (Invitrogen, USA) was used. The gel was stained with a mixture of 6X Blue Juice ( $0.4 \mathrm{~mL} \mathrm{0.5} \mathrm{M} \mathrm{10X} \mathrm{TAE,} 0.4 \mathrm{M}$ Tris-base, $34.8 \mathrm{M}$ acetic acid and 0.02 M EDTA; $0.2 \mathrm{~mL} \mathrm{10 \%} \mathrm{SDS;} 0.2 \mathrm{~mL}$ bromophenol blue; $7.0 \mathrm{~mL}$ glycerol; $1.7 \mathrm{~mL}$ sterile water) with 5X GelRed ( $1 \mathrm{~mL}$ 10,000X GelRed in $0.5 \mathrm{~mL}$ dimethyl sulfoxide (DMSO); $2 \mathrm{~mL}$ ultrapure water), at a 1:1 ratio. The image was revealed by the MiniBis Pro photo-documentation system.

The selection of primers (Table 1) was carried out, and amplification reactions were performed according to the protocol proposed by Williams et al. (1990) to obtain ISSR fragments, using a final volume of $20 \mu \mathrm{L}$. Each reaction contained the following: $2 \mu \mathrm{L} 10 \mathrm{X}$ buffer $(500 \mathrm{mM}$ $\mathrm{KCl}, 100 \mathrm{mM}$ Tris-HCl, pH 8.4), $2 \mu \mathrm{L} 25 \mathrm{mM} \mathrm{MgCl}$, $1.6 \mu \mathrm{L} 2 \mathrm{mM}$ dNTPs, $1 \mu \mathrm{L}$ DMSO, 1.8 $\mu \mathrm{L} 0.5 \mathrm{mM}$ primer, $0.12 \mu \mathrm{L} 5 \mathrm{U}$ Taq DNA polymerase and $2 \mu \mathrm{L} 5 \mathrm{ng}$ genomic DNA. The final volume was completed with ultrapure water. PCR for the marker was conducted as follows: $4 \mathrm{~min}$ at $94^{\circ} \mathrm{C}$, followed by 37 cycles $\left[94^{\circ} \mathrm{C}\right.$ for $1 \mathrm{~min}, 46^{\circ}$ to $50^{\circ} \mathrm{C}$ for $2 \mathrm{~min}$ (depending on the primer used) and $72^{\circ} \mathrm{C}$ for $2 \mathrm{~min}$ ], and a final extension at $72^{\circ} \mathrm{C}$ for $7 \mathrm{~min}$.

The products of the amplifications were separated on a $2.0 \%$ agarose gel. The marker used was 1-kb DNA Ladder (Invitrogen). The gel was stained with a mixture of 6X Blue Juice (0.4 mL 10X TAE, $0.5 \mathrm{M} ; 0.2 \mathrm{~mL} 10 \% \mathrm{SDS} ; 0.2 \mathrm{~mL}$ bromophenol blue, $7.0 \mathrm{~mL}$ glycerol; $1.7 \mathrm{~mL}$ sterile water) with $5 \mathrm{X}$ GelRed ( $1 \mu \mathrm{L}$ 10,000X GelRed in $0.5 \mathrm{~mL}$ DMSO, $2 \mathrm{~mL}$ ultrapure water) at a 1:1 ratio. The image was obtained by the MiniBis Pro photo-documentation system.

For the analysis of ISSR markers, the revealed gels were visualized and subsequently interpreted according to the presence and absence of bands, generating a binary matrix. The complement of Jaccard's similarity coefficient was used to estimate the genetic distances among the genotypes. A simplified representation of the genetic distances among the accessions was then carried out using the UPGMA (unweighted pair-group method using arithmetic average) clustering method and the principal coordinate analysis. The variability between and within the populations Piranão and Cimmyt was also assessed by analysis of molecular variance (MANOVA).

\section{RESULTS AND DISCUSSION}

\section{Assessment of full-sib progenies}

All traits were significant for the environments, demonstrating that the environments differed enough to allow differences among the traits (Table 1). Regarding the set effect, a significant effect was observed for most traits, except NE. This result reveals the effectiveness and necessity of using a block design split into sets. All traits revealed significant differences for the environment $\mathrm{x}$ set interaction, excepting NP and W100, indicating that the families were randomly distributed into the "sets", showing phenotypic changes stimulated by soil and climatic changes in the environments. 
Table 1. Estimate of the mean squares, averages and genetic parameters of six traits evaluated in 138 full-sib progenies of maize from the 11 th reciprocal recurrent selection cycle.

\begin{tabular}{|c|c|c|c|c|c|c|c|}
\hline \multirow[t]{2}{*}{ Source of variation } & \multirow[t]{2}{*}{ d.f. } & \multicolumn{6}{|c|}{ Mean square } \\
\hline & & NDF & NP & $\mathrm{NE}$ & W100 & WE & GY \\
\hline Environment (E) & 1 & $336.39^{* *}$ & $2196.13^{* *}$ & $798.20^{* * *}$ & $1189.86^{* *}$ & $99911345.61^{* * *}$ & $251532681.1^{* * *}$ \\
\hline Sets $(S)$ & 5 & $21.40^{* *}$ & $18.48^{* *}$ & 69.97 & $72.82^{* *}$ & $1437249.52^{*}$ & $4669034.2^{*}$ \\
\hline$E \times S$ & 5 & $23.14^{* *}$ & 10.96 & $83.34^{*}$ & 16.73 & $2266869.20^{* *}$ & $6015917.7^{* * *}$ \\
\hline Replications (R)/E x S & 12 & $33.95^{* *}$ & $10.79^{*}$ & $75.89^{*}$ & 14.35 & $2451020.85^{* *}$ & $7438730.6^{* *}$ \\
\hline Families $(\mathrm{F}) / \mathrm{S}$ & 132 & $16.38^{* *}$ & $13.53^{* *}$ & $72.32^{* *}$ & $22.91^{* *}$ & $1231798.20^{* * *}$ & $3621298.6^{* * *}$ \\
\hline $\mathrm{E} \times \mathrm{F} / \mathrm{S}$ & 132 & $8.34^{*}$ & 5.79 & 38.13 & 7.86 & $890748.43^{* *}$ & $2714704.1^{* *}$ \\
\hline Residual & 264 & 5.95 & 4.95 & 34.09 & 8.19 & 614004.44 & 187112.1 \\
\hline General average & & 72.90 & 23.11 & 31.01 & 30.88 & 3053.38 & 5008.14 \\
\hline \multicolumn{8}{|l|}{ Genetic parameter } \\
\hline$\sigma_{g}^{2}$ & - & 2.61 & 2.15 & 9.56 & 3.68 & 154448.40 & 437544.40 \\
\hline$\sigma_{f}^{2}$ & - & 4.09 & 3.38 & 18.08 & 5.73 & 307945.50 & 905324.60 \\
\hline CVe (\%) & - & 3.35 & 9.69 & 18.92 & 9.27 & 25.66 & 27.32 \\
\hline $\mathrm{CV}_{\mathrm{g}}$ & - & 2.21 & 6.37 & 9.97 & 6.21 & 12.87 & 13.21 \\
\hline$I_{v}$ & - & 0.65 & 0.66 & 0.53 & 0.67 & 0.50 & 0.48 \\
\hline$h^{2} \bar{X}_{f}$ & - & 63.68 & 63.39 & 52.87 & 64.27 & 50.15 & 48.33 \\
\hline
\end{tabular}

d.f. $=$ degrees of freedom; $\mathrm{NDF}=$ number of days for flowering; $\mathrm{NP}=$ average number of plants per plot; $\mathrm{NE}=$ average number of ears per plot; W100 = average weight of 100 grains in g; WE = average weight of ears in g/ plot; $\mathrm{GY}=$ grain yield in $\mathrm{kg} / \mathrm{ha} . \sigma_{g}^{2}=$ genotypic variance; $\sigma_{f}^{2}=$ phenotypic variance; $\mathrm{CVe}=$ experimental variation coefficient; $\mathrm{CV}_{\mathrm{g}}=$ genetic $\overline{\text { variation }}$ coefficient; $\mathrm{I}_{\mathrm{v}}=$ variation index; $h_{X_{f}}^{2}=$ heritability coefficient. $* \mathrm{P}<0.10$ and $* * \mathrm{P}<0.05$ (F-test).

All traits were significant for the source of family variation within set, demonstrating that there is enough genetic variability to be explored in future selection cycles (Table 1). The significance of NDF, WE and GY for the environment $x$ family interaction within the sets demonstrates that the families did not maintain the same phenotypic behavior in the two environments, indicating that the best families in a certain place may not be the best in a different location. However, the difference between the environments evaluated does not preclude the implementation of a single breeding program for the two locations, since, according to Santos (2005), the most important for selection is the expression of the phenotypic averages of the families in both environments. In such context, it is possible to achieve gains per selection, mainly using the potential of selection indices.

Regarding genetic parameters, the traits NDF, NP and W100 showed high estimates of genotypic variances and heritability values higher than $60 \%$, based on the average of the families, and variation rate with magnitudes higher than 0.60 (Table 1). For NE, WE and GY, the variation index was $0.53,0.50$ and 0.48 , respectively, whereas for heritability, it was 52.87 , 50.15 and 48.33 , respectively (Table 1 ). The results of this study agree with those obtained in previous cycles (Tardin et al., 2007; Gabriel, 2006, 2009).

The direct selection for grain yield provided adequate returns for the set of traits evaluated. The predicted selection gains were $-1.2,1.53,5.78,1.89,10.09$, and 10.46 for NDF, NP, NE, W100, WE, and GY, respectively. Figure 1 shows the boxplots for a $95 \%$ confidence interval, which represent the dimensions of variation of the traits evaluated for the progeny under study (138 interpopulation full-sib families) and the selected progeny (40 interpopulation full-sib families). For NDF, NP, NE, W100, WE, and GY, the expected gains were -0.87 days, 0.35 plants, 1.79 ears, $0.58 \mathrm{~g}, 308.21 \mathrm{~g} / \mathrm{plot}$, and $261.83 \mathrm{~kg} / \mathrm{ha}$, respectively. 

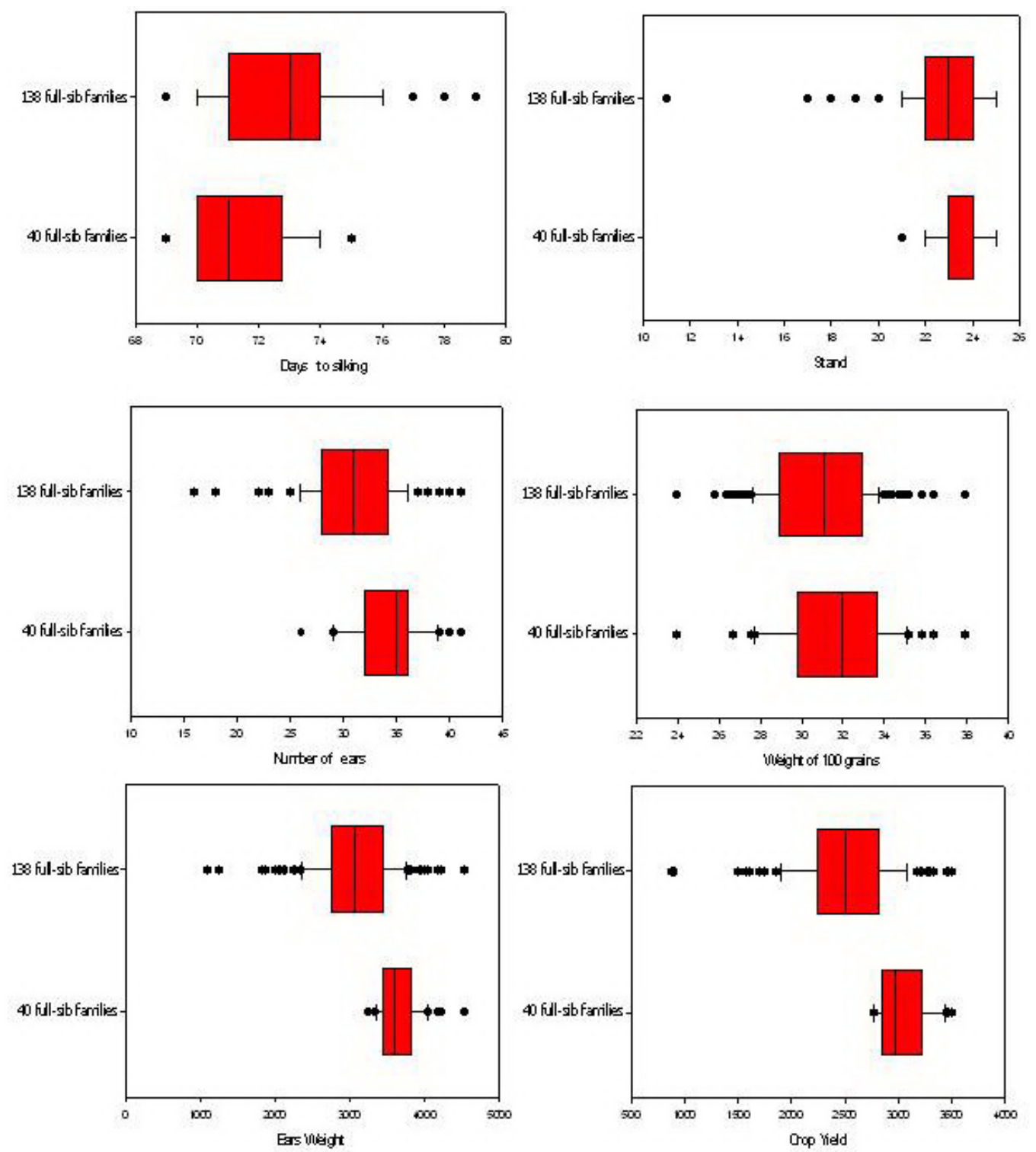

Figure 1. Boxplot for the traits flowering, stand, number of cobs, weight of 100 grains, weight of cobs, and grain yield for the progeny evaluated (138 interpopulation full-sib families) and the progeny selected (42 interpopulation full-sib families).

\section{Analysis of the ISSR markers}

By ISSR analysis, each primer produced bands of variable intensity, which could be easily detected, and nonspecific bands, which were discarded. The 23 primers used produced 118 bands (Table 2). Of these, 93 were polymorphic (78.81\%) and 25, monomorphic 
Table 2. List of primers used and number of amplified fragments and polymorphic ISSR.

\begin{tabular}{|c|c|c|c|}
\hline Oligonucleotide & Amplified fragments & Polymorphic fragments & Percentage of polymorphism \\
\hline$(\mathrm{AC})_{9}$ & 6 & 5 & 83.3 \\
\hline$(\mathrm{GA})_{9} \mathrm{~T}$ & 5 & 2 & 40.0 \\
\hline$(\mathrm{GA})_{8} \mathrm{CA}$ & 4 & 2 & 50.0 \\
\hline$(\mathrm{GA})_{8} \mathrm{GC}$ & 5 & 2 & 40.0 \\
\hline$(\mathrm{CAGA})_{4}$ & 4 & 3 & 75.0 \\
\hline$(\mathrm{CTC})_{5} \mathrm{RC}^{4}$ & 6 & 4 & 66.6 \\
\hline$(\mathrm{GA})_{8} \mathrm{YC}^{*}$ & 6 & 5 & 83.3 \\
\hline$(\mathrm{AC})_{8}^{8} \mathrm{~T}$ & 9 & 8 & 88.8 \\
\hline$(\mathrm{ATG})_{6}$ & 4 & 4 & 100.0 \\
\hline$(\mathrm{GT})_{8} \mathrm{YC}^{\circ} \mathrm{C}^{*}$ & 4 & 4 & 100.0 \\
\hline$(\mathrm{CT})_{8}^{8} \mathrm{RG}^{*}$ & 4 & 3 & 75.0 \\
\hline$(\mathrm{AG})_{8} \mathrm{YA} *$ & 3 & 2 & 66.6 \\
\hline$(\mathrm{AC})_{8} \mathrm{CT}$ & 5 & 4 & 80.0 \\
\hline$(\mathrm{AG})_{8}^{8} \mathrm{YT}^{*}$ & 4 & 3 & 75.0 \\
\hline$(\mathrm{CT})_{8}^{8} \mathrm{G}$ & 4 & 4 & 100.0 \\
\hline$(\mathrm{GTG})_{3} \mathrm{GC}$ & 4 & 2 & 50.0 \\
\hline$(\mathrm{AC})_{8} \mathrm{CG}$ & 4 & 2 & 50.0 \\
\hline$(\mathrm{GT})_{6}^{8} \mathrm{CC}$ & 10 & 9 & 90.0 \\
\hline$(\mathrm{CAC})_{3} \mathrm{GC}$ & 5 & 5 & 100.0 \\
\hline$\left(\mathrm{GGAT}_{3} \mathrm{GA}^{\mathrm{G}}\right.$ & 5 & 4 & 80.0 \\
\hline$(\mathrm{AC})_{8} \mathrm{YG}^{*}$ & 5 & 5 & 100.0 \\
\hline$(\mathrm{GAA})_{6} \mathrm{AA}$ & 5 & 4 & 80.0 \\
\hline$(\mathrm{AG})_{8} \mathrm{C}$ & 7 & 7 & 100.0 \\
\hline Total & 118 & 93 & 1773.6 \\
\hline Average & 5.1 & 4.0 & 77.1 \\
\hline
\end{tabular}

$* \mathrm{R}=\mathrm{A}, \mathrm{G} ; \mathrm{Y}=\mathrm{C}, \mathrm{T}$.

(21.19\%). The progenies C36 and P7 were the most distant (0.5657), while P22 and P23 were the most similar (0.2025).

UPGMA hierarchical clustering and principal coordinate analysis demonstrate that the populations Cimmyt and Piranão (Figure 2) were separated. Several subgroups were observed within these populations, demonstrating the existence of variability between and within the populations. These clustering results led to the conclusion that it is possible to achieve gains per se by means of selection, and that there are expectations to maximize heterosis in interpopulation crosses or among lines from these different populations. These results are consistent with those obtained by Tardin et al. (2007) and Berilli et al. (2011), who evaluated the genetic divergence between full-sib families of cycles 8 and 10, respectively, of the same populations under SRR.

It is well known that each cycle of recurrent selection basically involves three stages: i) development of progeny, ii) evaluation and selection of progeny, and iii) recombination of superior progeny. Therefore, the progeny selected and recombined must be sufficiently divergent so that the recombination process can restore genetic variability and ensure the continuity of the next cycles. In this context, the inclusion of molecular markers aims to identify reliably the maximum genetic variability within groups and maximize the intergroup genetic distance. Based on this assumption, the intermediate progeny between the populations Cimmyt and Piranão were eliminated, which consequently led to the maximization of the genetic distances between the populations (Figure 2).

A comparison between Figures 2 and 3 revealed that the molecular markers used at the selection stage contributed to the increased genetic distance between the two populations after the elimination of the intermediate genotypes. The populations studied were at the 11th cycle of the reciprocal recurrent selection, and from the 8th selection cycle, they have been monitored by 

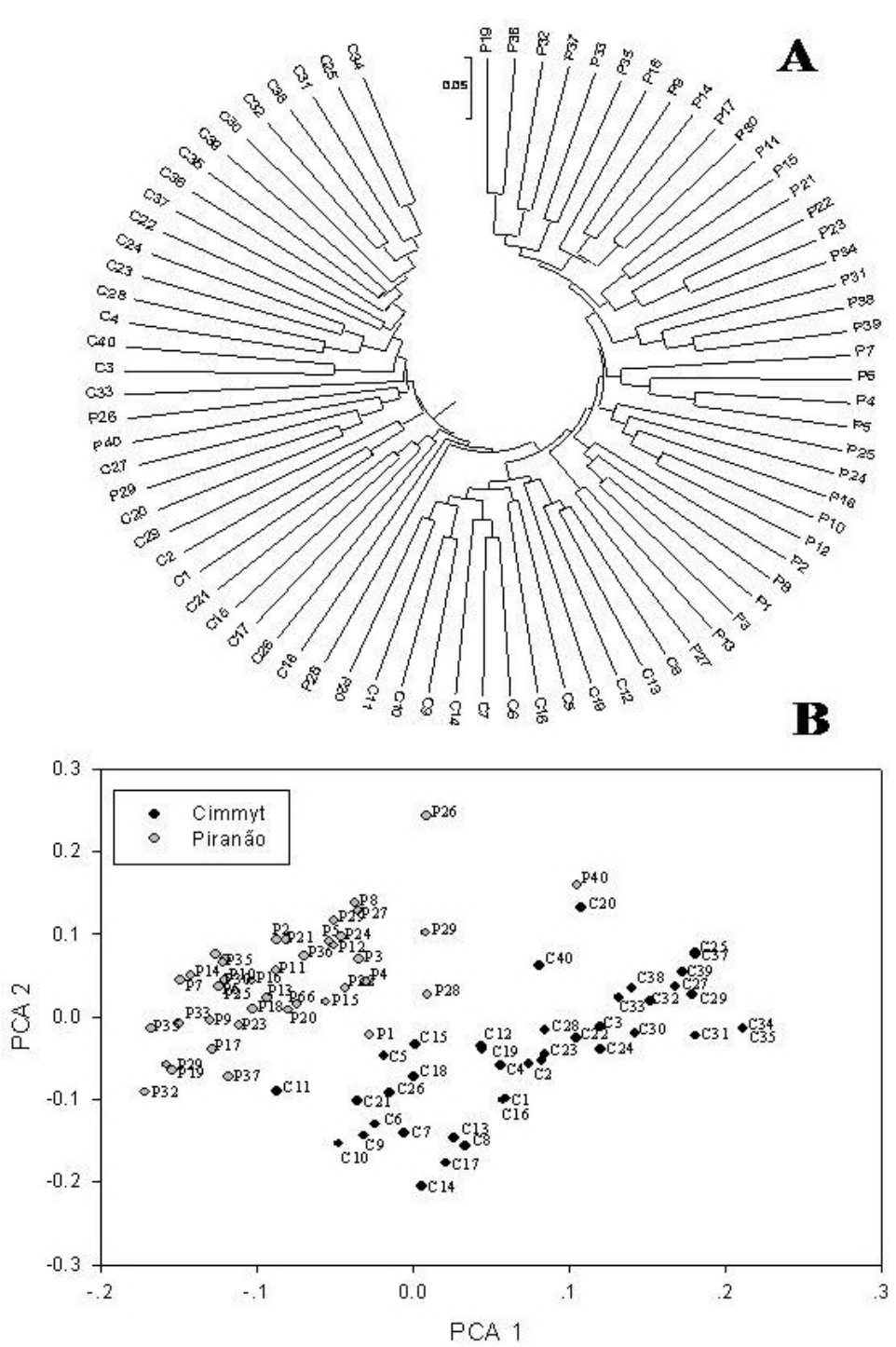

Figure 2. A. UPGMA dendrogram and B. principal coordinate analysis (PCA) of the $80 \mathrm{~S}_{1}$ progenies of the populations Cimmyt and Piranão, genotyped by ISSR markers.

molecular markers. The RAPD technique was applied at the 8th selection cycle (Tardin et al., 2007), AFLP, at the 9th cycle (Gabriel, 2006), and ISSR, at the 10th cycle (Berilli et al., 2011).

AMOVA of the $80 \mathrm{~S}_{1}$ progenies of the populations Cimmyt and Piranão revealed that the most genetic variation was within populations with $88.77 \%$, while between populations, it was $11.23 \%$ (Table 3 ). After the elimination of the contaminant progeny and selection of the most distant progeny, the genetic divergence between the populations increased to $17.67 \%$, and the distance within populations was $82.33 \%$. Berilli et al. (2011) evaluated the 11 th cycle and found the genetic variation of $10.16 \%$ between the populations, before the application 

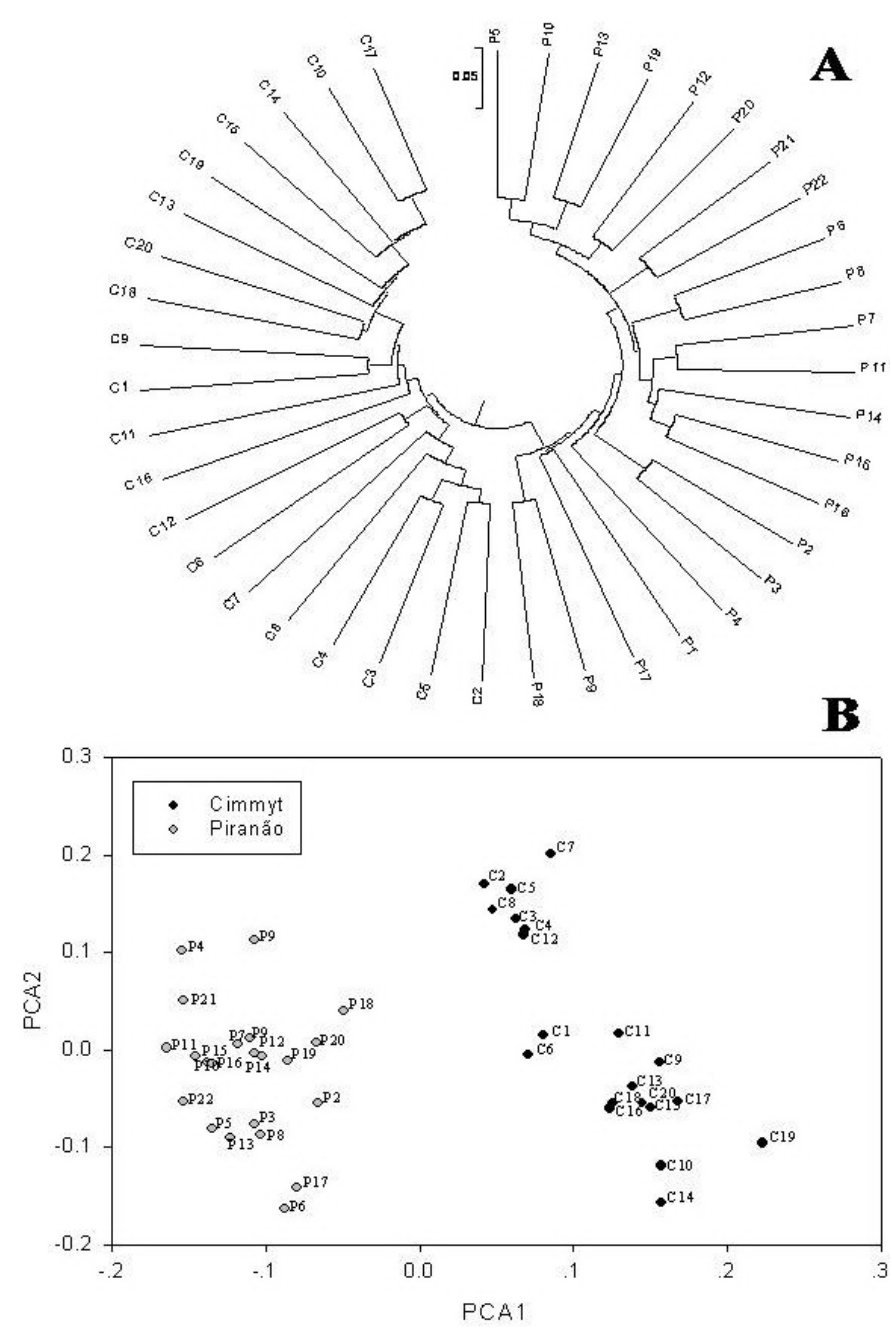

Figure 3. A. UPGMA dendrogram and B. principal coordinate analysis (PCA) of the $42 \mathrm{~S}_{1}$ progenies of the populations Cimmyt and Piranão, genotyped by ISSR markers.

\begin{tabular}{|c|c|c|c|c|c|}
\hline & d.f. & MS & Variance components & Percentage & Probability \\
\hline \multicolumn{6}{|l|}{ Before genotyping } \\
\hline Between populations & 1 & 99.10 & 2.0687 & 11.2306 & $<0.001$ \\
\hline Within populations & 78 & 16.3516 & 16.3516 & 88.7694 & $<0.001$ \\
\hline Total & 79 & 17.3991 & 18.4203 & 100 & $<0.001$ \\
\hline \multicolumn{6}{|l|}{ After genotyping } \\
\hline Between populations & 1 & 86.9584 & 3.3952 & 17.6688 & $<0.001$ \\
\hline Within populations & 40 & 15.8207 & 15.8207 & 82.3312 & $<0.001$ \\
\hline Total & 41 & 32.7727 & 19.2159 & 100 & $<0.001$ \\
\hline
\end{tabular}

d.f. $=$ degrees of freedom; MS $=$ mean squares of traits. 
of marker-assisted selection. After the application of marker-assisted selection, the variation between populations was $14: 28 \%$. Thus, it is clear that the application of molecular markers at the stage of superior genotype selection allows increased genetic distance between populations, a very important factor when the aim is to maximize the utilization of heterosis and provide higher longevity to the SSR program.

\section{REFERENCES}

Berilli AP, Pereira MG, Goncalves LS, da Cunha KS, et al. (2011). Use of molecular markers in reciprocal recurrent selection of maize increases heterosis effects. Genet. Mol. Res. 10: 2589-2596.

Bernardo R (2008). Molecular markers and selection for complex traits in plants: learning from the last 20 years. Crop Sci. 48: 1649-1664.

Comstock RE, Robinson HF and Harvey PH (1949). A breeding procedure designed to make maximum use of both general and specific combining ability. Agron. J. 41:360-367.

Daher RF, Pereira MG, Pereira AV and Amaral Júnior AT (2002). Genetic divergence among Elephantgrass cultivars accessed by RAPD markers in composite samples. Sci. Agric. 59: 623-627.

Doyle JJ and Doyle JL (1990). Isolation of plant DNA from fresh tissue. Focus 12: 13-15.

Fan XM, Zhang YD, Liu L, Chen HM, et al. (2010). Screening tropical germplasm by temperate inbred testers. Maydica 55: 55-63.

FAO (Food and Agriculture Organization of the United Nations) (2011). The agricultural production. Available at [http:// www.faostat.fao.org]. Accessed April 22, 2011.

Gabriel APC (2006). Seleção Recorrente Recíproca em Famílias de Irmãos Completos em Milho (Zea mays L.) Assistida por Marcadores Moleculares. Master's thesis, Universidade Estadual do Norte Fluminense Darcy Ribeiro, Campos dos Goytacazes.

Gabriel APC (2009). Seleção Recorrente Recíproca de Famílias de Irmãos Completos em Milho Comum (Zea mays L.) Monitorada por Marcadores Moleculares: Avanço de Gerações e Avaliação de Progresso Genético. Master's thesis, Universidade Estadual do Norte Fluminense Darcy Ribeiro, Campos dos Goytacazes.

Goodman MM (2005). Broadening the U.S. maize germplasm base. Maydica 50: 203-214.

Hallauer AR and Miranda Filho JB (1988). Quantitative Genetics in Maize Breeding. 2nd edn. Iowa State University Press, Ames.

Hallauer AR, Carena MJ and Miranda Filho JB (2009). Quantitative Genetics in Maize Breeding. Springer, New York.

Hartings H, Berardo N, Mazzinelli GF, Valoti P, et al. (2008). Assessment of genetic diversity and relationships among maize (Zea mays L.) Italian landraces by morphological traits and AFLP profiling. Theor. Appl. Genet. 117: 831-842.

Lynch M and Walsh B (1998). Genetics and Analysis of Quantitative Traits. Sinauer Associates, Sunderland.

Mikel MA and Dudley JW (2006). Evolution of North American dent corn from public to proprietary germplasm. Crop Sci. 46: 1193-1205.

Reif JC, Fischer S, Schrag TA, Lamkey KR, et al. (2010). Broadening the genetic base of European maize heterotic pools with US Cornbelt germplasm using field and molecular marker data. Theor. Appl. Genet. 120: 301-310.

Romay MC, Ordás B, Revilla P and Ordás A (2011). Three cycles of full-sib reciprocal recurrent selection in two Spanish maize populations. Crop Sci. 51: 1016-1022.

Santos FS (2005). Seleção Recorrente entre Famílias de Meios-Irmãos da População UNB-2U de Milho Pipoca (Zea mays L.). Doctoral thesis, Universidade Estadual do Norte Fluminense Darcy Ribeiro, Campos dos Goytacazes.

Smith JSC, Duvick DN, Smith OS, Cooper M, et al. (2004). Changer in pedigree backgrounds of Pioneer brand maize hybrids widely grown from 1930 to 1999. Crop Sci. 44: 1935-1946.

Souza CL Jr, Barrios SCL and Moro GV (2010). Performance of maize single-crosses developed from populations improved by a modified reciprocal recurrent selection. Sci. Agric. 67: 198-205.

Springer NM and Stupar RM (2007). Allelic variation and heterosis in maize: how do two halves make more than a whole? Genome Res. 17: 264-275.

Tardin FD, Pereira MG, Gabriel APC, Amaral Júnior AT, et al. (2007). Selection index and molecular markers in reciprocal recurrent selection in maize. Crop Breed. Appl. Biotechnol. 7: 225-233.

Williams JG, Kubelik AR, Livak KJ, Rafalski JA, et al. (1990). DNA polymorphisms amplified by arbitrary primers are useful as genetic markers. Nucleic Acids Res. 18: 6531-6535.

Genetics and Molecular Research 11 (3): 3398-3408 (2012) 